\title{
Puccorchidium and Sphenorchidium, two new genera of Pucciniales on Annonaceae related to Puccinia psidii and the genus Dasyspora
}

\author{
Ludwig Beenken ${ }^{1}$ - Alan R. Wood ${ }^{2}$ \\ Received: 27 February 2015 /Revised: 27 May 2015 / Accepted: 1 June 2015 /Published online: 16 June 2015 \\ (C) German Mycological Society and Springer-Verlag Berlin Heidelberg 2015
}

\begin{abstract}
Two-celled puccinioid teliospores are widely distributed in the rust fungi and appear in several independent lineages of the Pucciniales. About 25 genera in 4 families have been described. Species with two-celled teliospores occurring on members of the Annonaceae are described in the genera Dasyspora, Sphaerophragmium, Diorchidium, Puccinia, and Sphenospora. The molecular and morphological investigations from this study show that Diorchidium polyalthiae, Puccinia popowiae and Sphenospora xylopiae do not belong to the genera in which they were originally assigned. Aecidium deightonii was very closely related to $S$. xylopiae. Two new genera are erected to accommodate these taxa: (1) Puccorchidium, with the two species $P$. polyalthiae and P. popowiae; and (2) Sphenorchidium, with the two species S. xylopiae and $S$. deightonii. They form a well-supported clade in the Pucciniales together with the genus Dasyspora, which also occurs on Annonaceae species, and Puccinia psidii the cause of myrtle rust. The type species of the genus Diorchidium, D. woodii, as well as Sphenospora pallida and S. smilacina appeared within the genus Puccinia. The endocyclic species Endophylloides guineensis occurs on the same host and in the same area as S. xylopiae and S. deightonii,
\end{abstract}

Electronic supplementary material The online version of this article (doi:10.1007/s11557-015-1073-8) contains supplementary material, which is available to authorized users.

Ludwig Beenken

ludwig.beenken@env.ethz.ch

1 ETH Zurich, Institute of Integrative Biology, 8092 Zurich, Switzerland

2 ARC-Plant Protection Research Institute, P. Bag X5017, Stellenbosch 7599, South Africa but its relationship could not be determined without DNA data. A key for the rust fungi on Annonaceae with twocelled teliospores is given.

Keywords Diorchidium · Endophylloides · Puccinia · Sphenospora $\cdot$ Phylogeny $\cdot$ Two-celled teliospores

\section{Introduction}

The taxonomy of fungi was traditionally based on morphological data, but these classifications are often in conflict with phylogenies based on molecular data (e.g., Hawksworth 2012). Rust fungi (Basidiomycota, Pucciniales) are classified by morphological characteristics from several stages of their life cycles, namely spermogonia, aecia, telia and uredinia (e.g., Cummins and Hiratsuka 2003). The type of spermogonia and the form of teliospores are particularly important for the delimitation of families and genera (Cummins and Hiratsuka 2003). The number of cells and their dividing septa are the characters of teliospores used to distinguish genera with pedicillate teliospores. Number and position of germpores as well as the wall ornamentation of teliospores were also used. Based on these characteristics, Cummins and Hiratsuka (2003) listed 25 genera in 4 families that have two-celled, pedicellate teliospores. They distinguished two spore types according to the orientation of the cells: the Puccinia-like (puccinioid) type with two cells vertically in a row relative to the pedicel placement (horizontal orientation of septum) versus the Diorchidium-like (diorchidioid) type with two cells horizontally in a row (vertical orientation of septum). Recently, molecular phylogenetic studies show that such morphologically defined families (Aime 2006; Beenken et al. 2012) and genera (Aime 2006; Maier et al. 2007; van der 
Merwe et al. 2008; Minnis et al. 2012) are polyphyletic and thus artificial.

On species of Annonaceae, several rust fungi with twocelled teliospores have been described in the genera Dasyspora (Beenken et al. 2012), Sphaerophragmium (Beenken and Berndt 2010), Diorchidium (Sydow and Sydow 1915), Puccinia (Cooke 1882) and Sphenospora (Yen and Sulmont 1970). The present study deals with the phylogenetic relationship of species of the three latter genera on the Annonaceae, which had an unclear systematic position in a previous study (Beenken et al. 2012).

The genus Diorchidium, as circumscribed in Cummins and Hiratsuka $(1983,2003)$ and Hennen et al. (1998), is a morphologically variable group including species with teliospores that differ from each other in number of cells ( 2 or 4), wall ornamentation and position of germ-pores. All have the common character of vertical septation in the teliospores. Cummins and Hiratsuka (1983, 2003) placed Diorchidium in the Raveneliaceae based mainly on the presence of spermogonia of group VI, type 7. However, spermogonia are only known from 2 of the 12 species assigned to Diorchidium (Hennen et al. 1998), and not of the type species of the genus, D. woodii Kalchbr. \& Cooke (Doidge 1927). Thus, the classification of most species in this genus is uncertain and the genus Diorchidium is probably polyphyletic, as was similarly shown for the genus Puccinia (Aime 2006; van der Merwe et al. 2008; Minnis et al. 2012). Beenken and Berndt (2010) transferred Diorchidium gerstneri (Doidge) A.R. Wood to Sphaerophragmium as S. gerstneri (Doidge) Beenken \& R. Berndt, which left one described species of Diorchidium on Annonaceae: Diorchidium polyalthiae Syd. occurring on Polyalthia longifolia (Sonn.) Thwaites in India and Sri Lanka. Beenken et al. (2012) showed that D. polyalthiae does not belong to the Raveneliaceae, but is a sister species to Puccinia popowiae Cooke on Monanthotaxis caffra Verdc. These two taxa were more closely related to Dasyspora than to Puccinia. A further genus with diorchidioid teliospores is Sphenospora, which is morphologically similar to Diorchidium (Hennen et al. 1998). A single species occurs on Annonaceae: Sphenospora xylopiae J.M. Yen \& Sulmont on Xylopia aetiopica A. Rich. in Gabon, the only extra-American species not on a monocot host (Hennen et al. 1998).

Puccinia psidii G. Winter (myrtle rust), an important pathogen on Myrtaceae that is invasive in several tropical and subtropical countries, has an ambiguous systematic position (van der Merwe et al. 2008; Tan et al. 2014; Pegg et al. 2014). It was included in the present study as it is closely related to the fungi investigated here and Dasyspora. This is the fourth part in a series of monographic studies of rust fungi on the Annonaceae (Beenken and Berndt 2010; Beenken et al. 2012; Beenken 2014).

\section{Materials and methods}

\section{Fungal collection and morphology}

Herbarium specimens were loaned from B, BPI, K, M, NY, PREM, PC, PUR, S and Z+ZT (acronyms according to Index Herbariorum; Thiers 2011). Morphology was studied by light microscopy of spores and hand sections through fungal structures as described in Beenken et al. (2012). Measurements of 25 spores are given as minimum-arithmetic mean-maximum or minimum-maximum, as relevant. Length-width ratios are given as length/width. Terminology of spermogonia types was used according Cummins and Hiratsuka (2003).

\section{Molecular investigations}

DNA was extracted using NucleoSpin Plant II extraction kits (Macherey-Nagel, Düren, Germany) following the manufacturer's standard protocol for plant tissue with the modifications described in Beenken (2014). PCR amplification and sequencing follow exactly the protocol in Beenken et al. (2012) using the following primer combinations: ITS1-5.8SITS2: ITS5-u/ITS4rust or ITS5-u/Rust2 and Rust2inv/ ITS4rust; partial $L S U$ : LRust1R/LR6 or LRust1R/LRust3 and LRust3R/LR6; SSU: NS1/ NSrust3R and NSrust2/ Rust18SR or NS1/NSrust1R, NSrust1/NSrust2R, NS3/ NSrust3R, NSrust2/NSrust5R, NS5/NSrust7R and NSrust6/ Rust18SR (Pfunder et al. 2001; Beenken et al. 2012; Kropp et al. 1997; Aime 2006; Vilgalys and Hester 1990; White et al. 1990). Sequences were deposited in GenBank (accession numbers in Table 1).

\section{Alignment}

The sequences were assembled with Sequencher v.4.10.1 (Gene Codes, Ann Arbor, MI, USA) and aligned with MacClade 4.06 (Maddison and Maddison 2003). Species compositions were taken from preliminary studies (Aime 2006; Beenken et al. 2012; Beenken 2014; Tan et al. 2014; Pegg et al. 2014). Alignments were refined using MUSCLE v.3.6 (Edgar 2004). Ambiguously aligned regions were delimited and excluded from phylogenetic analyses with Gblocks v.0.91b (Castresana 2000). Two datasets were created: (1) a combined SSU-LSU dataset consisting of 56 taxa and 2 sub-matrices (SSU with 1633 sites, LSU with 811 sites); and (2) an ITS-LSU dataset consisting of 13 taxa and 1641 nucleotide sites. Accession numbers of sequences taken from GenBank are given in Fig. 1 and Fig. S1.

\section{Phylogenetic analyses}

The aligned datasets were analyzed as in Beenken (2014) using maximum likelihood (ML) methods as implemented 
Table 1 Specimens and GenBank accession numbers used in the phylogenetic analyses

\begin{tabular}{|c|c|c|c|c|c|c|c|}
\hline Species & Host & Location & Spore-stage & Isolate & Herbarium voucher & ITS-LSU & SSU \\
\hline Aecidium deightonii & Xylopia aethiopica & Guinea & $0, \mathrm{I}$ & 245 & PC 0096730 & KM217350 & KM217368 \\
\hline Aecidium deightonii & Xylopia aethiopica & Gabon & $0, \mathrm{I}$ & 331 & PC 0096724 & KM217351 & KM217369 \\
\hline Diorchidium polyalthiae & Polyalthia longifolia & India & I, III & 16 & RB-251 (in ZT) & $J F 263493^{\mathrm{a}}$ & $\mathrm{JF} 263509^{\mathrm{a}}$ \\
\hline Diorchidium woodii & Millettia grandis & South Africa & III & 255 & ZT Myc 582 & KM217352 & KM217370 \\
\hline Macruropyxis fraxini & Fraxinus platypoda & Japan & III & 227 & ZT Myc 56551 & KP858145 & KP858144 \\
\hline Puccinia popowiae & Monanthotaxis caffra & South Africa & III & 38 & ZT Myc 1977 & KM217353 & - \\
\hline Puccinia popowiae & Monanthotaxis caffra & South Africa & I & 39 & ZT Myc 1976 & $\mathrm{JF} 263495^{\mathrm{a}}$ & $\mathrm{JF} 263511^{\mathrm{a}}$ \\
\hline Sphenospora kevorkianii & Stanhopea candida & Peru & III & - & BPI 863558 & DQ354521 ${ }^{\mathrm{b}}$ & DQ354520 \\
\hline Sphenospora smilacina & Smilax sp. & Brazil & III & 293 & ZT Myc 44038 & KM217354 & KM217371 \\
\hline Sphenospora xylopiae & Xylopia aethiopica & Gabon & III & 248 & NY s.n. & KM217355 & KM217372 \\
\hline
\end{tabular}

${ }^{\mathrm{a}}$ From Beenken et al. (2012)

${ }^{\mathrm{b}}$ From Amie (2006)

in RAxML v.7.2.8 (Stamatakis 2006) and additionally with Bayesian analyses performed with MrBayes 3.2.1 (Huelsenbeck and Ronquist 2001; Ronquist and Huelsenbeck 2005). For the SSU-LSU dataset, Caeoma torreyae was selected as outgroup (cf. Aime 2006). For the ITS-LSU dataset, Aecidium verannonae was used as outgroup following the SSU-LSU phylogeny (Fig. 1). All analyses were performed assuming a general time reversible model of nucleotide substitution (GTR), estimating a discrete gamma distribution (GTRGAMMA option in RAxML). One thousand runs with distinct starting trees were completed for each dataset using the rapid bootstrap algorithm of RAxML (Stamatakis et al. 2008). Three independent Bayesian runs were conducted for every dataset, each with four chains and 10,000,000 generations, sampling every 100th tree. Post-burn-in trees (burn-in of 1,000,000 generations) were collected and the summarizations calculated only when the standard deviation of split frequencies had reached levels below 0.01. To further ensure that the runs reached stationarity and converged on the same lnlikelihood scores, the resulting likelihoods, tree topologies and model estimates were examined and compared using the program Tracer v.1.6.0 (Rambaut et al. 2014). Posterior probability values equal to or greater than 0.95 were considered significant. Lower posterior probability values are given if the corresponding ML bootstrap values were higher than $50 \%$. Phylogenetic trees were visualized using the program Dendroscope (Huson et al. 2007).

\section{Result}

The resulting trees of the RAxML and Bayesian analyses showed a more or less congruent topology. The ML analysis from the combined SSU-LSU dataset is shown in Fig. 1. The resulting tree of the ITS1-5.8S-ITS2-LSU ML analysis is given in the supplemental material (Fig. S1).
The genera Diorchidium, Puccinia and Sphenospora are polyphyletic in the present phylogeny based on LSU and SSU sequences of the n-rDNA (Fig. 1). The four species on Annonaceae, namely Diorchidium polyalthiae, Puccinia popowiae, Sphenospora xylopiae and Aecidium deightonii, together with the genus Dasyspora and P. psidii, formed a well-supported clade that is distantly related to the Puccinia/ Uromyces clade. Diorchidium polyalthiae and P. popowiae are well-supported sister species and in sister position to S. xylopiae and A. deightonii, which are very closely related. The phylogenetic analysis using the combined ITS-LSU sequences supported these relationships (Fig. S1). The aecia of collection ZT Myc 1976 (DNA isolate 39) have the identical ITS sequence as the telia of P. popowiae (ZT Myc 1977, DNA isolate 38 ) confirming its identity. Pairwise comparisons (identity in \%) of the ITS, LSU and SSU sequences, respectively, within this group are given in Table S1.

The type species of the genus Diorchidium, D. woodii, was placed within the Puccinia/Uromyces clade, within the subclade containing the type species of Uromyces (Link) Unger, U. appendiculatus F. Strauss (Puccinia clade I in Fig. 1). Sphenospora smilacina Syd. and S. kevorkianii Linder also appeared in close relationship to the genus Puccinia. They formed a well-supported monophyletic subclade in sister position to the clade containing Macuropyxis fraxini (Kom.) Azbukina and Puccinia physalidis Peck.

\section{Taxonomy}

Puccorchidium Beenken, gen. nov.

MycoBank number MB 809626

Spermogonia unknown. Aecia single or in groups, of Aecidium-type, cup shaped; aeciospores polyhedral to subglobose, wall thin, ornamentation of fine verruculose to verrucose warts and refractive granules; peridial cells in front view broad ovoid, ornamentations of inner sides fine verrucose; outer side ornamentations verrucose with merging warts. Uredinia unknown. 


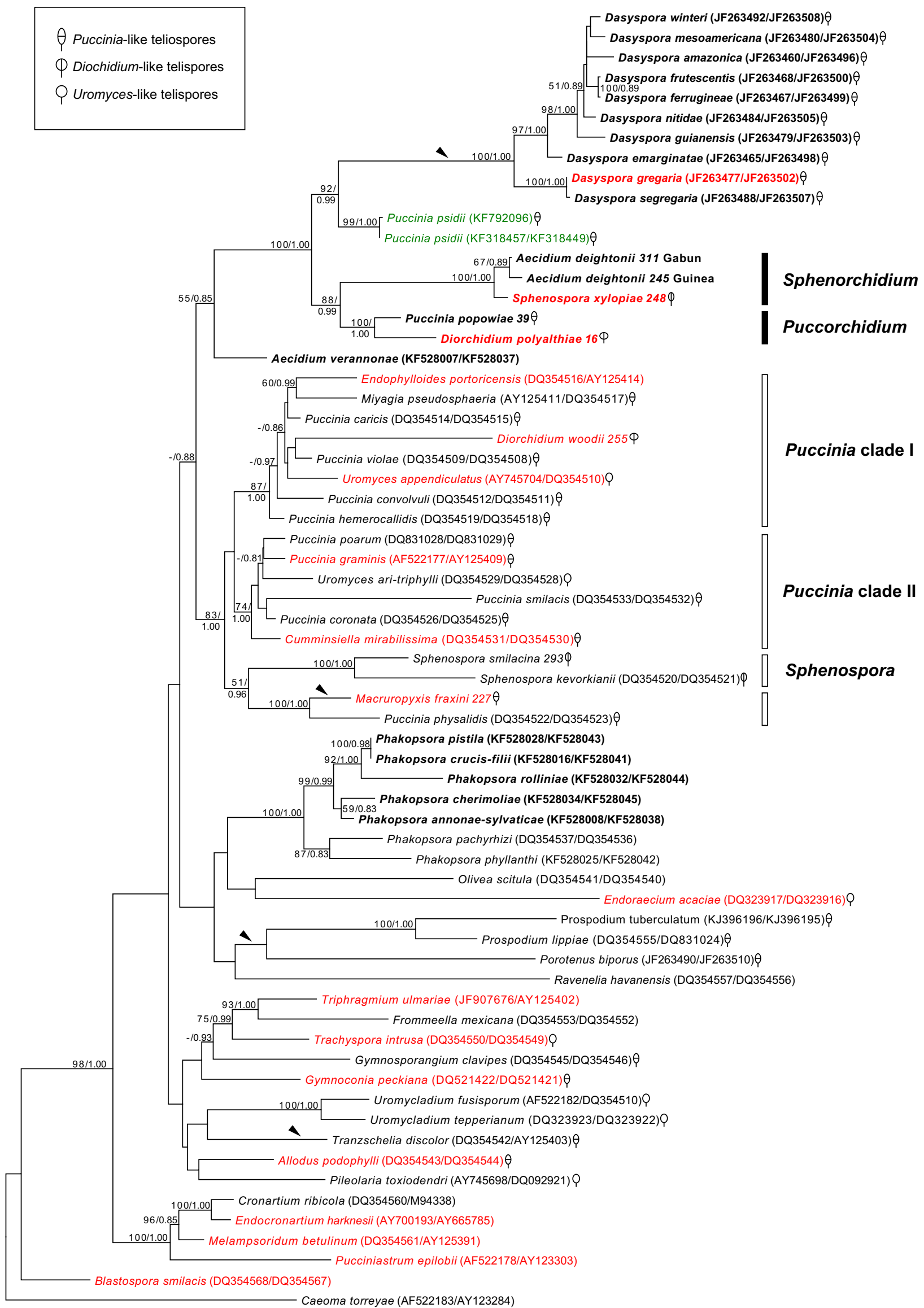


4 Fig. 1 Positions of the new genera Puccorchidium and Sphenorchidium (black bars) within the Pucciniales and their relationship to the genera Diorchidium, Sphenospora and Puccinia within the Pucciniaceae (white bars). The several septation types of teliospores are indicated by pictograms (legend in graphic); species on Annonaceae are in bold; type species of genera in red; Puccinia psidii in green. Arrowheads indicate clades with species assigned to Uropyxidaceae. Maximumlikelihood analysis with RAxML v.7.2.6 recovered from combined LSU-SSU sequence data. Numbers at nodes indicate RAxML bootstrap support $>50 \%$ / Bayesian posterior probabilities $>0.80$. GenBank accession numbers of LSU/SSU in parentheses, respectively, in Table 1; numbers in italic assign the DNA-isolates in Table 1

Telia with aecia on the same host, subepidermal, erumpent, powdery, dark brown. Teliospores two-celled by vertical, oblique or horizontal septa; walls two-layered with a thick, light brown pigmented inner layer and a thin, colorless outer layer; germ-pores one per cell, not distinct margined but formed by an area of gradually thinned wall at each pole of the teliospore; ornamentation of acuminate or truncate spines more or less thick-walled.

\section{Type species of the genus: Puccorchidium polyalthiae (Petch) Beenken}

Etymology: A composition of Puccinia and Diorchidium.

Puccorchidium polyalthiae (Petch) Beenken, comb. nov. MycoBank number MB 809627

Fig. 2
Basionym: Aecidium polyalthiae Petch, Ann. R. bot. Gdns Peradeniya 5(4): 241 (1912)

= Diorchidium polyalthiae Syd., in Sydow H. and Sydow, P., Annals mycol. 13(1): 35 (1915)

Spermogonia unknown. Aecia single or in groups on chlorotic leaf spots up to $5 \mathrm{~mm}$ in diameter, spots often bordered by a black line, on abaxial and rarely adaxial leaf surfaces, cup-shaped emerging from a collar-like margin of slightly hypertrophied plant tissue, 130-200 $\mu \mathrm{m}$ high and 150 $200 \mu \mathrm{m}$ in diameter; aeciospores polyhedral to subglobose, 13-14.3-16×10-13.1-15 $\mu \mathrm{m}$, length/width 1-1.11-1.6, wall $0.3 \mu \mathrm{m}$ thin, ornamentation of fine verruculose to verrucose warts and refractive granules $2 \mu \mathrm{m}$ high and $3 \mu \mathrm{m}$ in diameter; peridial cells broad ovoid, 18-20.3-22 $\mu \mathrm{m}$ long, 15-16.7$19 \mu \mathrm{m}$ wide, length/width $1-1.23-1.57$, wall up to $1 \mu \mathrm{m}$ thick; ornamentations of inner sides fine verrucose; outer side ornamentations verrucose with merging warts, in side view outer wall $1 \mu \mathrm{m}$ thick with rod-like warts up to $2 \mu \mathrm{m}$ high. Uredinia unknown.

Telia on abaxial and adaxial leaf surfaces, scattered or in small groups, sometimes associated with aecia, subepidermal, erumpent, powdery, dark brown, up to $500 \mu \mathrm{m}$ in diameter; teliospores two-celled by vertical septum, rarely with oblique or horizontal septum, slightly constricted at the septum, 24

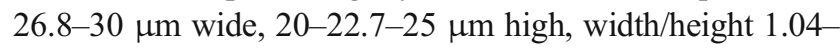
$1.18-1.27$, walls two-layered, inner layer $1-2 \mu \mathrm{m}$ thick, light brown, outer layer $0.2-0.5 \mu \mathrm{m}$ thin, colorless, germ-pores one

\section{Fig. 2 Puccorchidium}

polyalthiae: a aecium ( $\mathrm{R}$. Berndt no. B-251) in section; b telia (M-0142442) on both sides of a leaf in section; $\mathbf{c}, \mathbf{d}$ teliospores (M-0142442) in optical section and surface view, arrows point to the thinner spore wall of the germpores; e aberrant teliospore with horizontal septum; $\mathbf{f}$ close up of a spine showing its hollow space. d-f Stained with cotton blue
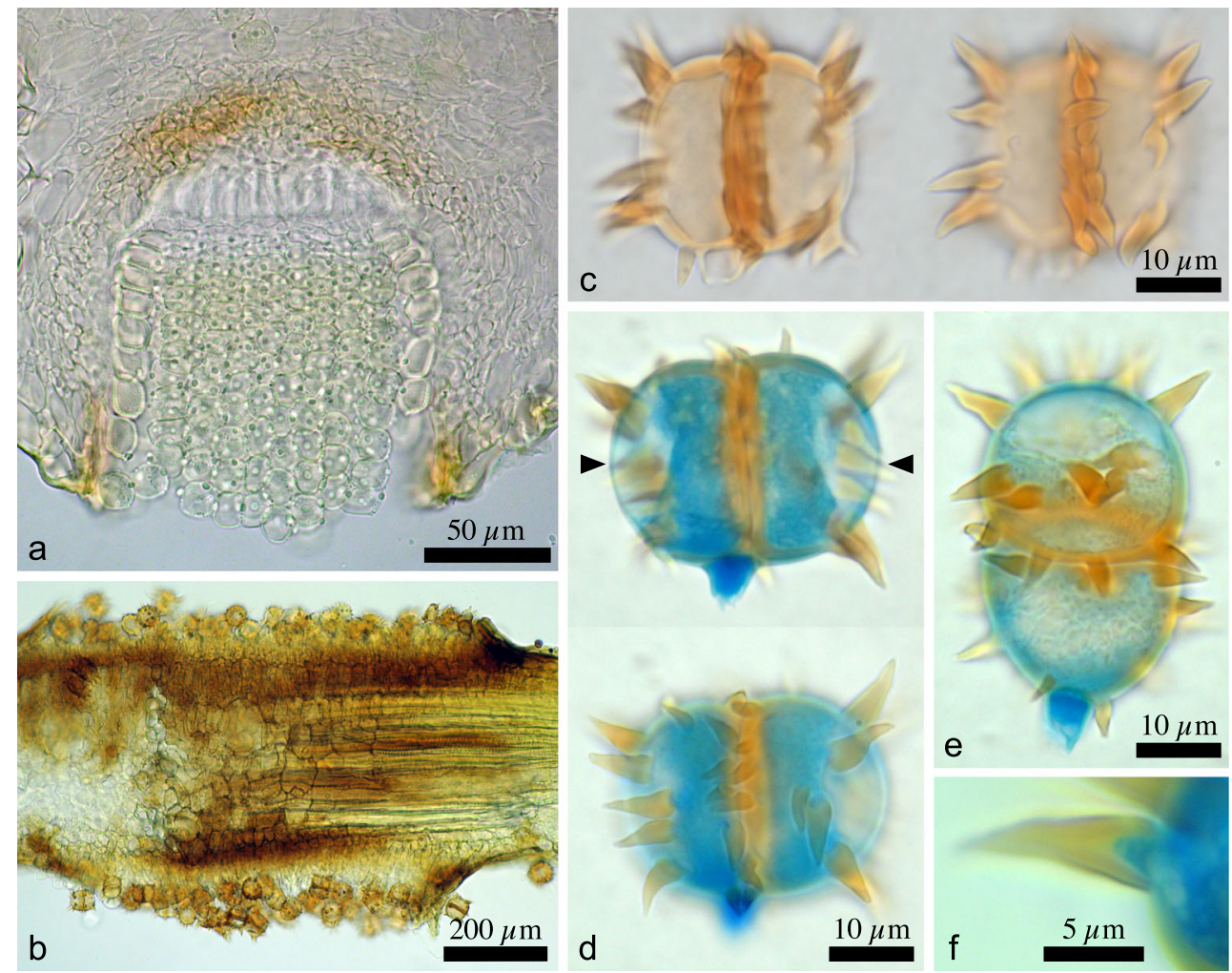
per cell, indistinct, thinner-walled areas $(0.5 \mu \mathrm{m}$ thin) lateral at the poles of the spore, ornamentation of spines arranged in one circle around each pole and on both sides along the septum, respectively, spines conical, acuminate up to $10 \mu \mathrm{m}$ long, basally 3-4 $\mu \mathrm{m}$ wide, hollow with 1 - to $1.5-\mu \mathrm{m}$-thick walls; pedicel inserted at the septum or next to it, rarely laterally at the spore basal pole, broken-off shortly.

On leaves of Polyalthia longifolia (Sonn.) Thwaites in India and Sri Lanka.

Holotype: SRI LANKA, 1910, leg. T. Petch no. 3080 (holotype of Aecidium polyalthiae: K 181932) (I).

Epitypes designated here: SRI LANKA, Peradeniya, 21 Jan. 1914, leg. T. Petch, Sydow, fungi exotici exsiccati 477 (M-0142442=lectotype (designated here) of Diorchidium polyalthiae; isotypes: B 700014112, BPI s.n., NY 00053718, PUR F2209, S F27668, S F27669, S F27670, Z Myc 06536, ZT Myc 44012)

Additional specimens: SRI LANKA, Peradeniya, 09 Apr. 1919, leg. T. Petch, as A. polyalthiae (S F36350) (I); INDIA, Karnataka State, Mysore University Campus, 2 Nov 1995, leg. R. Berndt no. B-251 (ZT) (I, III), DNAisolate 16.

Note on the nomenclature: The anamorph-typified Aecidium polyalthiae is the oldest name of the species and has priority over the teleomorph-typified Diorchidium polyalthiae (article 59 in McNeill et al. 2012; cf. Beenken 2014). Therefore it has to be the basionym. An epitype is designated here to define explicitly the species (and the new genus) including telial characteristics.

\section{Puccorchidium popowiae (Cooke) Beenken \& A.R.} Wood, comb. nov.

Basionym: Puccinia popowiae Cooke, Grevillea 10 (56): 126 (1882)

$\equiv$ Dicaeoma popowiae (Cooke) Kuntze, Revis. gen. pl. (Leipzig) 3(2): 470 (1898)

MycoBank number MB 809628

Fig. 3

Spermogonia unknown. Aecia single or in groups, on abaxial leaf surface, cup shaped emerging from a collar-like margin of slightly hypertrophied plant tissue, 150-200 $\mu \mathrm{m}$ high and $170-240 \mu \mathrm{m}$ in diameter; aeciospores polyhedral to subglobose, 10-11.5-13×8-9.5-11 $\mu \mathrm{m}$, length/width 1-1.221.63 , wall $0.3 \mu \mathrm{m}$ thin, ornamentation fine-verruculose to verrucose warts and refractive granules $1-2 \mu \mathrm{m}$ high and 2-3 $\mu \mathrm{m}$ in diameter; peridial cells in front view broad ovoid, 15-17.3$20 \mu \mathrm{m}$ long, $10-12.3-14 \mu \mathrm{m}$ wide, length/width 1.14-1.431.72 , wall up to $1 \mu \mathrm{m}$ thick; ornamentations of inner side fineverrucose; outer side ornamentations verrucose with warts merging to be labyrinthiform, in side view outer wall $1 \mu \mathrm{m}$ thick with rod like warts up to $2 \mu \mathrm{m}$ high. Uredinia unknown.

Telia on abaxial and rarely on adaxial leaf surfaces, scattered or in small groups, sometimes associated with aecia, subepidermal, erumpent, powdery, dark blackish-brown, up to $500 \mu \mathrm{m}$ in diameter; teliospores two-celled by horizontal, rarely oblique or vertical septum, constricted at the septum, 28-30.4-33 $\mu \mathrm{m}$ long, 21-22.6-24 $\mu \mathrm{m}$ wide, length/width $1.12-1.35-1.50$, walls two-layered, inner layer $1.5-2 \mu \mathrm{m}$ thick, brown pigmented, outer layer $0.2-0.5 \mu \mathrm{m}$ thin, color-
Fig. 3 Puccorchidium popowiae: a-c aecium (ZT Myc 1976), a aeciospores; b peridial cells in optical section; c outer surface of peridial cells; $\mathbf{d}-\mathbf{g}$ teliospores (PREM 10499) in optical section and surface view with septa in different orientations, arrowheads point to germ-pores. f Stained with cotton blue
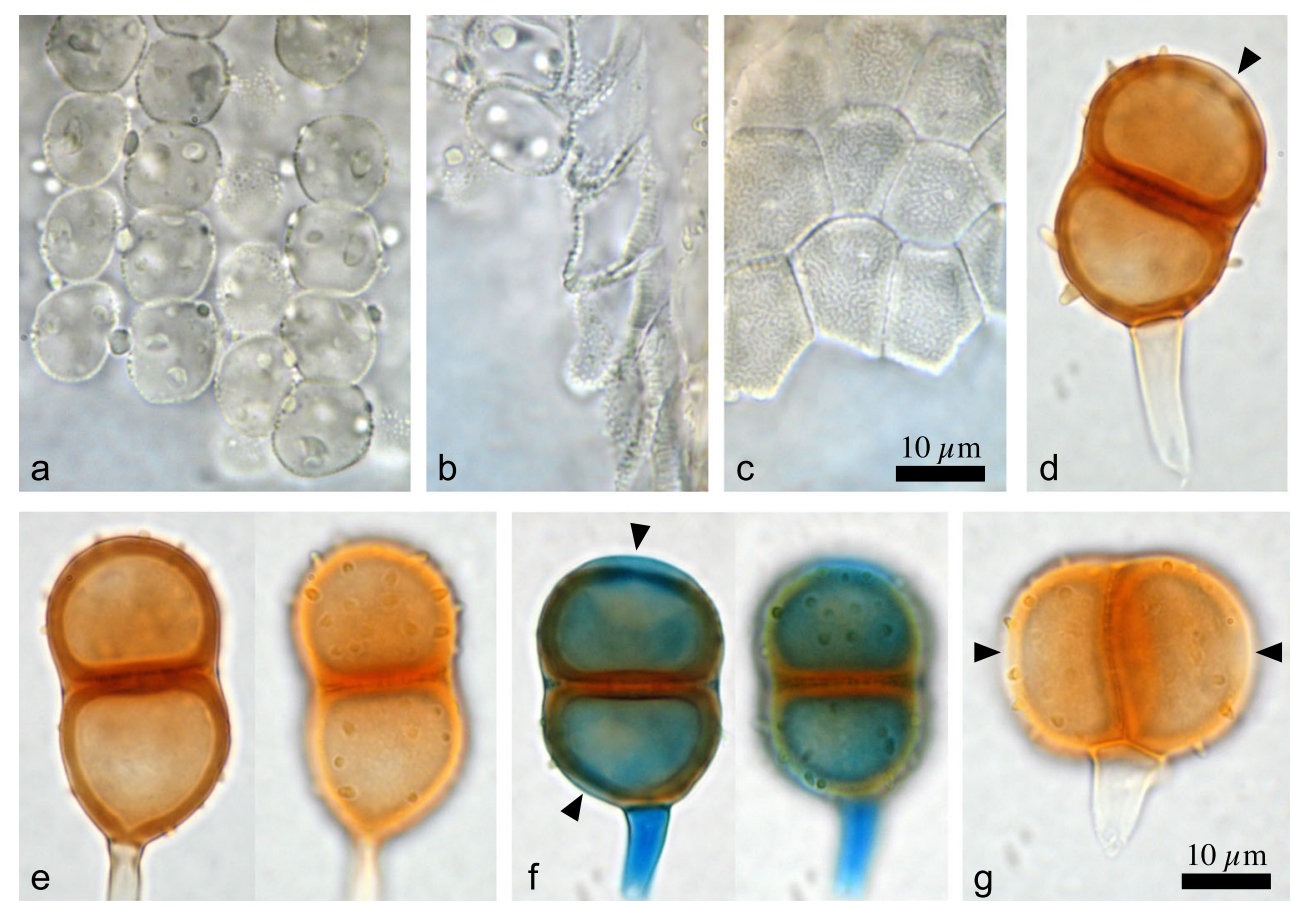


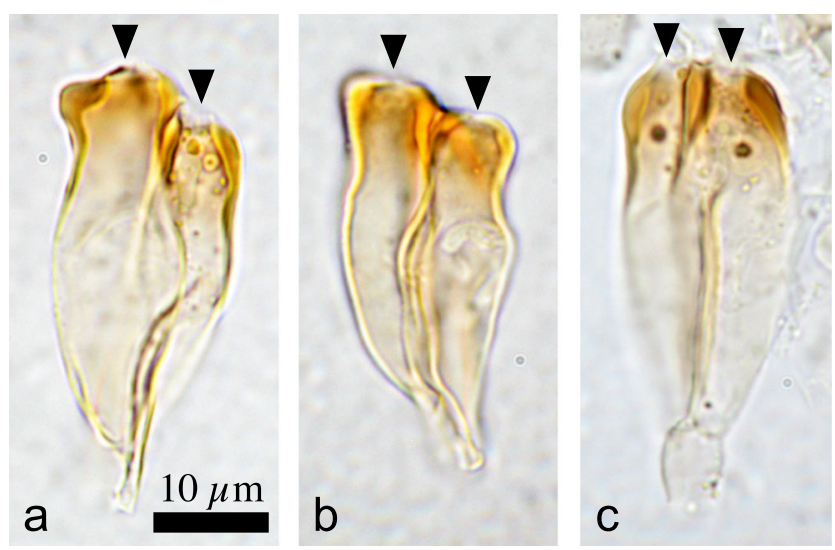

Fig. 4 Sphenorchidium xylopiae (PC 0096711): a-c teliospores in optical section, arrowheads point to germ-pores

less, germ-pores one per cell, indistinct, thinner-walled areas ( $0.5 \mu \mathrm{m}$ thin) at the poles of the spore, respectively next to the pedicel, ornamentation of irregularly scattered, thin-walled $(0.5 \mu \mathrm{m})$, conical spines with rounded tips, up to $2 \mu \mathrm{m}$ long, basally $1-1.5-2 \mu \mathrm{m}$ wide; pedicel inserted at, or slightly offcenter of, the basal pole of the spore, rarely laterally of it or close to the septum.

On leaves of Monanthotaxis caffra (Sond.) Verdc. (= Popowia caffra (Sond.) Hook. f. \& Thomson ex Benth.) in South Africa.

Types: South Africa, KwaZulu-Natal, Inanda Jun. 1881, leg. Medley Wood no. 614 (Holotype: PREM 10499; isotype BPI US0093869) (III).

Additional specimens: SOUTH AFRICA, KwaZulu-Natal, Winters Kloof, 13 Sep. 1919, leg. E. M. Doidge (PREM 12433, BPI US0093868) (III); - , Durban, Isipingo Bush, 10 Nov. 1940, leg. V. A. Wager (PREM 32415) (I, III); -, Kloof, Kloof Nature Reserve, $29^{\circ} 46^{\prime} \mathrm{S} 30^{\circ} 49^{\prime} \mathrm{E}, 25$ Feb. 2009, leg. A. R. Wood no. 746 (ZT Myc 1976, PREM) (I) (DNA isolate 39); —, —, 15 Jun. 2009, leg. A. R. Wood no. 748 (ZT Myc 1977, PREM) (I, III) (DNA isolate 38).

\section{Sphenorchidium Beenken, gen. nov.}

\section{MycoBank number MB 809629}

Spermogonia and aecia in groups on leaf spots. Spermogonia subepidermal, subglobose, of group V, type 4 . Aecia of Aecidium-type, cup shaped; aeciospores polyhedral to globose, wall thin, colorless to pale yellow, ornamentation coarsely verrucose, equatorially with flat warts, with refractive granules; peridial cells in front view ovoid, wall ornamentations of inner sides densely verruculose, of outer side verrucose. Uredinia unknown.

Telia and teliospores similar to those of the genus Sphenospora Dietel but without an oily gelatinous matrix; teliospores pedicellate, two-celled by vertical septa with one apical germ-pore per cell as in Sphenospora but with apical wall thickenings around germ-pores; germination without dormancy, external metabasidia.
Host plants dicotyledonous, not monocotyledonous as in Sphenospora.

Etymology: A composition of Sphenospora and Diorchidium.

Type species of the genus: Sphenorchidium xylopiae (J.M. Yen \& Sulmont) Beenken

Sphenorchidium xylopiae (J.M. Yen \& Sulmont) Beenken, comb. nov.

Basionym: Sphenospora xylopiae J.M. Yen \& Sulmont, Bull. trimest. Soc. mycol. Fr. 85(3): 352 (1970) [1969]

MycoBank number MB 809630

Fig. 4

Spermogonia, aecia and uredinia unknown. Telia abaxial on leaves, subepidermal, erumpent, compact, dark brown, up to $450 \mu \mathrm{m}$ in diameter, arranged in concentric circles on chlorotic leaf spots of $1-5 \mathrm{~mm}$ diameter; pedicellate teliospores two-celled by vertical septum, ellipsoid to invert-ovoid, 28 $35 \times 12-16 \mu \mathrm{m}$, length/width c. $1.75-2.5$, collapsing after germination; one distinct apical germ-pore per cell, wall smooth, light-brown, laterally and at the septum up to $0.5 \mu \mathrm{m}$ thick, apically around the germ-pores up to $2 \mu \mathrm{m}$ thick, germination without dormancy, by external metabasidia, pedicels persistent, paraphyses not observed.

On leaves of Xylopia aethiopica A. Rich. in Gabon, western Central Africa.

Holotype: GABON, 25 Aug. 1968, G. Gilles (according Yen and Sulmont 1970, type specimen not found)

Additional specimens: GABON, Libreville, Forêt de la Mondah, Km 27.3, 7 Dec. 1969, leg. G. Gilles (PC 0096711); -, Km 28, 30 Jan. 1971, leg. G. Gilles (P.G. no.4) (NY s.n.) (DNA-isolate 248).

Sphenorchidium deightonii (Syd.) Beenken, comb. nov.

Basionym: Aecidium deightonii Syd., Annals mycol. 35(3/4): 256 (1937)

= Aecidium xylopiae ss. Viennot-Bourgin (1959 pp. 16-17) not A. xylopiae Henn. Hedwigia 34: 100. 1895

MycoBank number MB 809631

Fig. 5

Spermogonia and aecia in large groups on discolored (light brown in herbarium specimens) leaf spots 5-20 mm diameter, not hypertrophied. Spermogonia adaxial, light brown to black, of group V, type 4, subepidermal, subglobose, 130-150 $\times 120$ $130 \mu \mathrm{m}$. Aecia of Aecidium-type, abaxial, cup shaped, 350 $400 \mu \mathrm{m}$ in diameter, 400-450 $\mu \mathrm{m}$ high, surrounded by white to yellowish peridia split in several lobes; aeciospores polyhedral to globose, 15-16.8-19×15-15.4-17 $\mu \mathrm{m}$, length/width 1-1.09-1.36, wall $0.5 \mu \mathrm{m}$ thick, colorless to pale yellow, ornamentation coarsely verrucose, equatorially with a band of flat warts $0.3-1 \mu \mathrm{m}$ in diameter, refractive granules $2-3 \mu \mathrm{m}$ high and $2.5-5 \mu \mathrm{m}$ in diameter. Peridial cells in front view ovoid, 22-25.8-31 $\mu \mathrm{m}$ long, 15-17-20 $\mu \mathrm{m}$ wide, length/ width 1.15-1.54-2.00, wall $1.5-2 \mu \mathrm{m}$ thick, ornamentations of inner wall densely verruculose with merging warts, 
Fig. 5 Sphenorchidium deightonii (PC 0096728): a aecium in section; $\mathbf{b}$ spermogonium in section; $\mathbf{c}$ inner surface of peridial cells, stained with cotton blue; $\mathbf{d}$ aeciospores in surface view
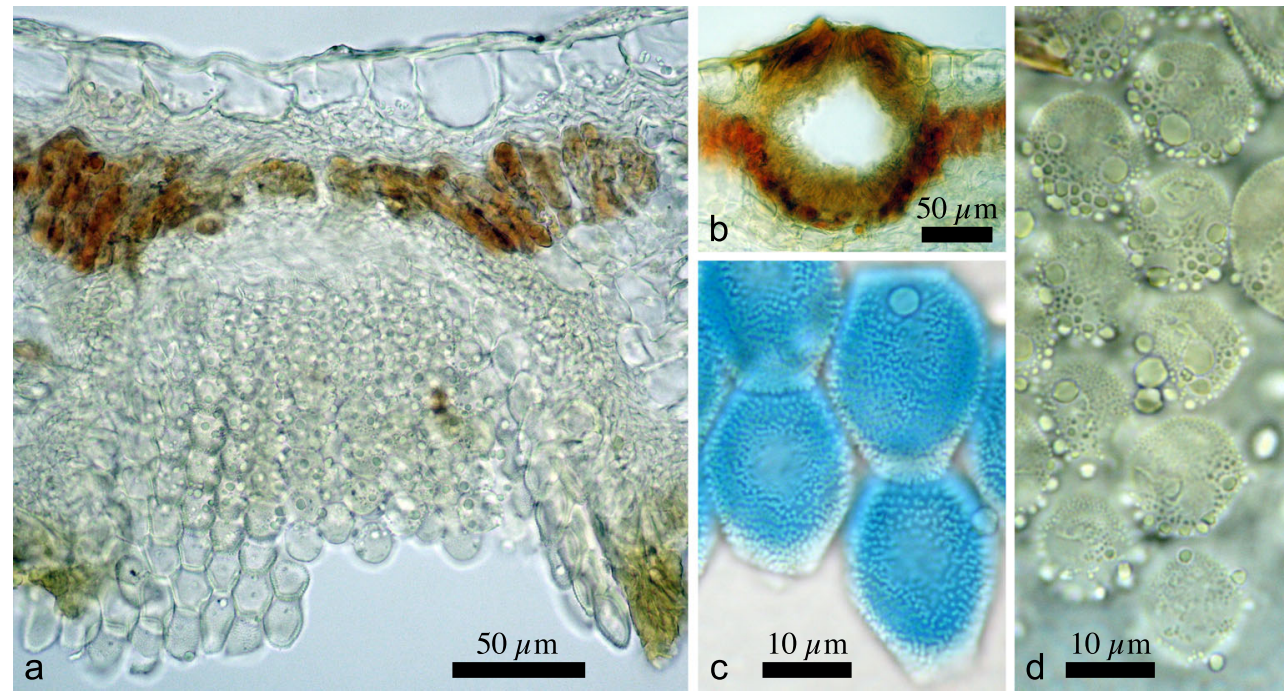

labyrinthiform, outer wall ornamentations verrucose, in side view warts rod-like $3 \mu \mathrm{m}$ high. Telia and uredinia unknown.

On leaves of Xylopia aethiopica in West Africa and western Central Africa.

Holotype: SIERRA LEONE, Nyeyama (Peri), 14 Apr. 1929, leg. F.C. Deighton no. M263 (K [M] 181941)

Additional specimens: GABON, Rouille, 27 Oct. 1969, leg. G. Gilles (PC 0096724) (DNA isolate 311). GUINEA, Près de Farmoréah, rout de Fansiga, basse Guinée, Jan. 1957, leg. G. Viennot-Bourgin no. 309 (PC 0096729); Près de chutes de la Kilissi, Jan. 1957, leg. G. ViennotBourgin no. 319 (PC 0096730) (DNA-isolate 245); Boqueteau près de Kigbali, Benty, basse Guinée, Jan. 1957, leg. G. Viennot-Bourgin no. 296 (PC 0096731); Region of Mt. Nimba, Mar. 1942, leg. Schnell (PC 0096723 ex herb. G. Viennot-Bourgin). IVORY COAST, Adiopodoumé, 25 Aug. 1951, leg. Luc (PC 0096727); —, 16 Oct. 1951 (PC 0096728); Banco at Abidjan, 28 Jan. 1957, leg. Kern (ZT Myc 54740) (DNA-isolate 244); Mt. Nimba, 21 Dec. 1951, leg. Th. Monod (PC 0096725). SIERRA LEONE, Sulima (Gbema), 30 Mar. 1939, leg. F.C. Deighton no. M1934 (PC 0096715 ex K/IMI no. 43126, PUR F9557, BPI US0151890 ex PUR).

Note on the nomenclature: According to the International Code of Nomenclature for algae, fungi and plants from 2011 (Melbourne Code) Article 59 (McNeill et al. 2012), it is not necessary to know the teleomorphic stage of an anamorphic species to assign it to a teleomorphic genus. Consequently, Aecidium deightonii was recombined as Sphenorchidium deightonii based on the molecular data.

Note: Both species of Sphenorchidium occur on $X$. aethiopica but they differ in their spore stages. Telia are only known from $S$. xylopiae, whereas spermogonia and aecia are only known from $S$. deightonii. This suggests that both could be different spore stages in the life cycle of one single species. However, the different spore stages were not found together on a leaf or in a collection, as was the case for the species of Puccorchidium. In addition, there were distinct differences between their sequences of ITS, LSU and SSU, which indicated that S. xylopiae and S. deightonii are not conspecific.

Endophylloides guineensis Vienn.-Bourg., Annals Inst. natn. agron., Paris 45: 21, 25 (1959)

$\equiv$ Ceratocoma guineensis (Vienn.-Bourg.) Buriticá, Revta Acad. colomb. cienc. exact. fis. nat. 18 (no. 69): 146 (1991), name invalid according McNeill et al. (2012, Art. 41.4)

Fig. 6

Spermogonia and telia on leaf spots $2-4 \mathrm{~mm}$ in diameter. Aecia and uredinia unknown. A stroma like 20-30 (50) $\mu \mathrm{m}$ thick plectenchymatous hyphal layer fills the space between epidermis cells and mesophyll cells on the adaxial leaf side in the area of the leaf spots. Spermogonia subepidermal, embedded in this hyphal layer, disk-shaped, of group VI, type 5, $180-200 \mu \mathrm{m}$ in diameter, $70-80 \mu \mathrm{m}$ high. Telia aecidoid, sunk deeply in the abaxial leaf tissue, which is coated by a $10-40 \mu \mathrm{m}$ thick hyphal layer forming a sheath $120-160 \mu \mathrm{m}$ in diameter and 180-300 $\mu \mathrm{m}$ high; without peridia or paraphyses; teliospores adherent, arranged in compact, cylindrical columns, $80-100 \mu \mathrm{m}$ in diameter, up to $300 \mu \mathrm{m}$ long, single teliospores subglobose to ovoid, 18-30 in diameter, wall smooth, colorless, up to $1 \mu \mathrm{m}$ thin, germ-pores obscure, germination without dormancy, occasionally intercalary cells of 8-11 $\times 4-6 \mu \mathrm{m}$ seen between the teliospores. Metabasidia two- or three-celled, $10 \mu \mathrm{m}$ wide.

On leaves of Xylopia aetiopica in West Africa.

GUINEA, Bokaria, Jan. 1957, leg. Viennot-Bourgin no. 305 (Isotype: PUR F18317)

Note: The present description summarizes ViennotBourgin's (1959) more detailed description and excellent illustrations combined with own observations. 
Fig. 6 Endophylloides guineensis (PC F18317): a spermogonium in section (arrowhead pointed to the pore), imbedded in a stroma-like hyphal layer between upper epidermis and mesophyll cells; $\mathbf{b}$ close up of hyphal layer; $\mathbf{c}$ teliospores with smaller intercalary cell between them; $\mathbf{d}$ telium in section with teliospores arranged in a column
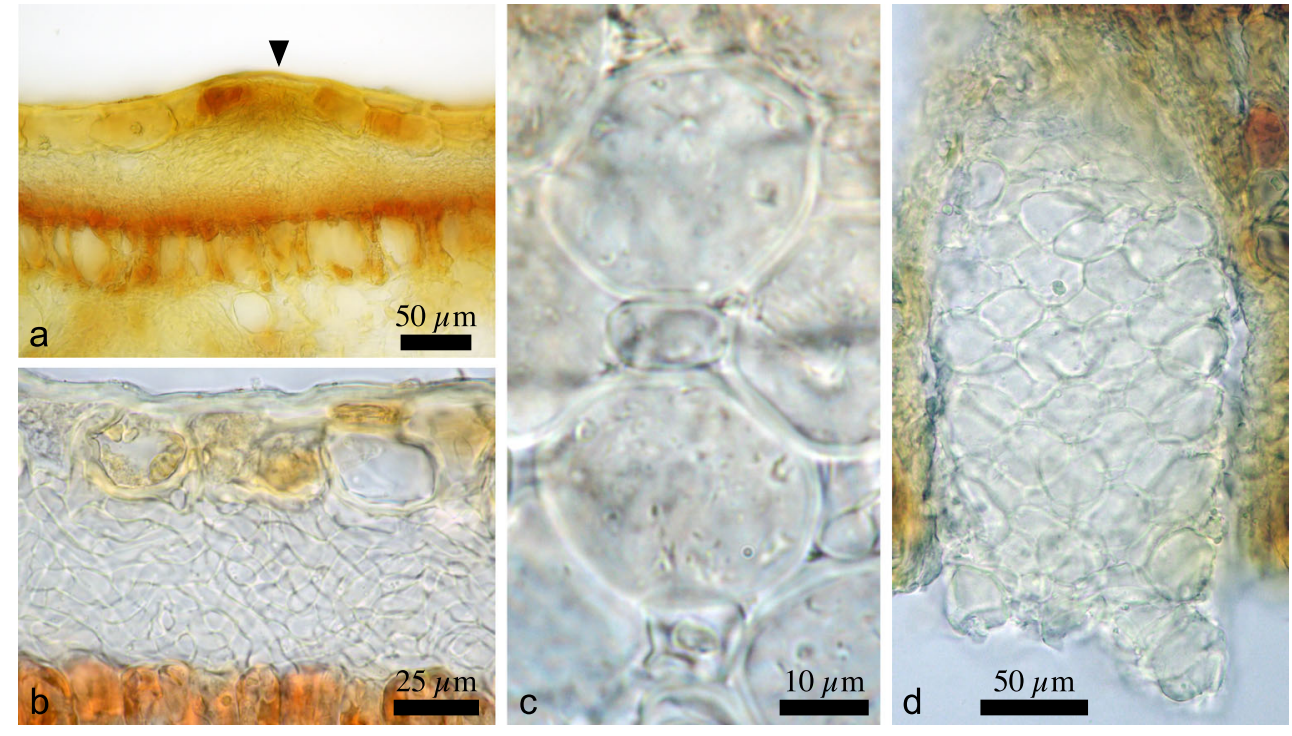

\section{Additional species investigated for the study}

Diorchidium woodii Kalchbr. \& Cooke (Fig. 7)

SOUTH AFRICA, KwaZulu-Natal, Durban, Yellowwood

Park, Kenneth Stainbank Nature Reserve, on Millettia grandis Skeels, 14 Dec. 2006, leg. A. R. Wood no. 700 (ZT Myc 582, PREM 60110) (DNA isolate 255); -, Umkomaas, on Millettia caffra Mesn., 24 Apr 1919, leg. A. M. Bottomley (ZT Myc 8696, PREM 11893).

Diorchidium acanthostephum Syd.

ECUADOR, prov. Napo-Pastaza, Puyo, on Pithecolobium sp., 23 Feb 1938, leg. H. Sydow, Fungi exotici exsiccati 1103 (Z Myc 06535), Fungi Aequatorienses 888 (ZT Myc 44009).

Diorchidium koordersii Wurth

INDONESIA, Java, Bagelen, on Derris montana Benth., 1905, leg. S.H. Koorders (ZT Myc 44011).

Sphenospora pallida (G. Winter) Dietel

ECUADOR, prov. Napo-Pastaza, Puyo, on Dioscorea sp., 20 Feb 1938, leg. H. Sydow, Fungi exotici exsiccati 1096 (Z Myc 06540), Fungi Aequatorienses 880 (ZT Myc 44037).

Sphenospora smilacina Syd.

BRAZIL, Ceará, Guaramiranga, on Smilax sp., 12 Jan 2006, leg. F. Freire no. 8582 (ZT Myc 44038) (DNA isolate 293). ECUADOR, prov. Napo-Pastaza, Puyo, on Smilax cumanesis Willd., 17 Feb 1938, leg. H. Sydow, Fungi Aequatorienses 868 (ZT Myc 44039).

\section{Key to the rust fungi on Annonaceae with two-celled teliospores}

1 Cells of teliospores elongated, septa vertical, walls smooth, distinctly thickened around the apical germ-pores........ Sphenorchidium xylopiae
$1^{*}$ Cells of teliospores more or less isodiametric, septa horizontal, oblique or vertical, walls ornamented, more or less equally thick.

2 Spore ornamentation heteromorphic: spores apically and basally with long, rod-like projections branched at the tip and laterally with flatted, hemispherical or conical warts, septum horizontal Dasyspora (key in Beenken et al. 2012)

$2 *$ Spore ornamentation uniform. ... 3

3 Spore ornamentation of bifurcate projections, septa vertical, pedicels persistent at the spores, long, pedicel walls gelatinous, rugose, swelling in $\mathrm{KOH}$........ Sphaerophragmium gerstneri (Beenken and Berndt 2010)

3* Spore ornamentation of simple spines, pedicels with smooth walls

4 Spines acuminate, up to $10 \mu \mathrm{m}$ long, arranged around the spore poles and along the septa, septa mostly vertical. Puccorchidium polyalthiae

4* Spines with rounded tips, up to $2 \mu \mathrm{m}$ long, irregularly scattered, septa mostly horizontal.... Puccorchidium popowiae

\section{Discussion}

\section{Phylogeny}

The molecular phylogeny using LSU and SSU sequences has shown unambiguously that Diorchidium polyalthiae, Puccinia popowiae and Sphenospora xylopiae did not belong to the genera where they were respectively assigned, and that they are related to the genus Dasyspora, which also occurs on Annonaceae (Fig. 1).

Reference sequences were obtained from other members of these genera for comparison. The type species of the genus Diorchidium, D. woodii, belongs to the Pucciniaceae s.str. and 
Fig. 7 Diorchidium woodii (ZT Myc 582): a-c teliospores: $\mathbf{a}$ in optical section; $\mathbf{b}$ in surface view; c view on the lateral pole; arrowheads point to germ-pores

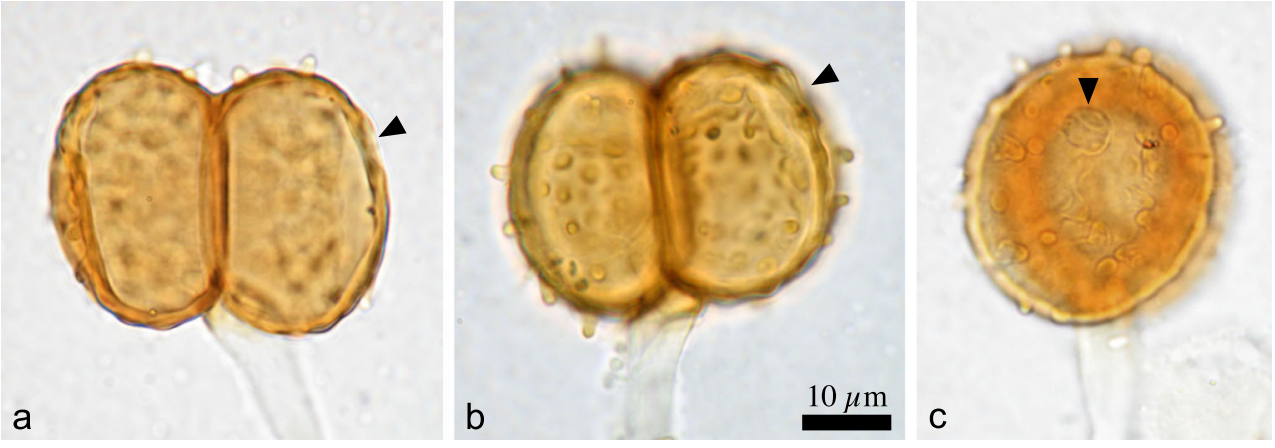

to the genus Puccinia s.l. Its position was in the clade of $U$. appendiculatus (= clade I in van der Merwe et al. 2008; Puccinia group I in Minnis et al. 2012). Van der Merwe et al. (2008) reported that Uromyces species with telia on Fabaceae appear mainly in this clade. Diorchidium woodii occurs on Millettia, also in the Fabaceae. Sphenospora smilacina was chosen for the analyses, because it is a close relative of the type species of the genus, S. pallida (Sydow 1925; Jackson 1926; Arthur 1926), from which DNA was not successfully extracted. This species and S. kevorkianii also appeared in the broader Puccinia clade, but they did not belong to either of the two main clades of Puccinia s.l. (cf. Aime 2006). The taxonomy and nomenclature of Diorchidium and Sphenospora will be resolved in parallel to the Puccinia-Uromyces complex, which includes representatives of other genera such as Cumminsiella Arthur, Dietelia Henn, Macruropyxis Azbukina and Miyagia Miyabe ex Syd. \& P. Syd. (Aime 2006; van der Merwe et al. 2008).

The molecular analysis in this study supported the description of two new genera: (1) Puccorchidium, with the two species $P$. polyalthiae and $P$. popowiae; and (2) Sphenorchidium, with the two species S. xylopiae and S. deightonii.

\section{Morphology}

Cummins and Hiratsuka (1983, 2003) differentiated Diorchidium from Puccinia by having spermogonia of group VI, type 7 , in contrast to group V, type 4 . However, spermogonia have never been reported for the type species of Diorchidium, D. woodii (Kalchbrenner and Cooke 1882; Hennen et al. 1998; own observations). Thus, there is no morphological evidence against the molecular result that $D$. woodii belongs to Puccinia. Puccinia-like and Diorchidium-like septated teliospores appear in several linages of the Pucciniales (Fig. 1). The orientation of septa in teliospores is variable within Puccinia (e.g., Magnus 1891; Doidge 1927; Gäumann 1959; Cummins 1971). This character is not useful to define genera. In Diorchidium, spermogonia are only known from D. puiggarii Speg. and D. taiwanensis R. Berndt, which are of type 7 in both species (Hennen et al. 1998;
Berndt 1996). These two species as well as Diorchidium koordersi Wurth [= Diphragmium koordersi (Wurth) Boedijn] closely resembles the genus Hapalophragmium Syd. \& H. Syd. (Berndt 1996; Hennen et al. 1998), which has type 7 spermogonia and three-celled teliospores (Lohsomboon et al. 1992). Diorchidium as defined by Cummins and Hiratsuka (2003) is polyphyletic, with members belonging to at least three distant lineages within the Pucciniales.

The teliospores of Puccorchidium polyalthiae and $P$. popowiae can be distinguished morphologically from $D$. woodii by their germ-pores. These are formed by indistinct, thinner-walled areas at the spore poles of $P$. polyalthiae and P. popowiae (Figs. 2, 3) but are distinct and sharply defined perforations in the spore walls of D. woodii (Fig. 7). Diorchidium acanthostephum on Pithecellobium sp. (Fabaceae) from Brazil is the most similar species to P. polyalthiae and P. popowiae and may be related to them. It has two-celled teliospores with vertical septa, a two-layered spore wall that is thinner at the germ-pores located at the lateral spore poles, and ornamentation of spines (Hennen et al. 1998; own observations). Unfortunately, DNA could not be extracted successfully from the available material, thus molecular data to determine its systematic position are still lacking.

Sphenorchidium xylopiae differs from all the species of Sphenospora as the teliospores have a thickened wall around the germ-pores and the telia are not embedded in a gelatinous matrix. The following species were combined or described in Diorchidium based on the aforementioned morphology of telia and teliospores: D. baphiae Ritschel, Berndt \& Oberw. (Ritschel et al. 2007), D. copaiferae (Henn.) Cummins \& Y. Hirats. (Cummins and Hiratsuka 1983) and D. dalbergiellae (Vienn.-Bourg.) Ritschel, Berndt \& Oberw. (Ritschel et al. 2007). Their teliospores are similar to those of $S$. xylopiae. They have two-celled teliospores by vertical septa, have one apical germ-pore per cell and have smooth walls that are thickened apically around the pores. They differ from S. xylopiae in having curved paraphyses and reniform urediniospores. Their host plants belong to the Fabaceae (Cummins and Hiratsuka 1983, 2003; Hennen et al. 1998; Ritschel et al. 2007; ViennotBourgin 1958). Molecular analyses will be necessary to 
determine their relationships and systematic positions. However, the superficial similarity of thin-walled teliospores in these species, Sphenorchidium and Sphenospora s.str. can be explained by independent, convergent adaptions from loss of dormancy before germination that makes thick walls unnecessary. Such thin-walled lepto-types are well known from several genera of Pucciniales (e.g., Gäumann 1959; Cummins and Hiratsuka 2003).

The new genus Sphenorchidium is also ecologically separated from Sphenospora s.str. In contrast to Sphenorchidium xylopiae, which occurs on the dicotyledonous Xylopia aethiopica, Sphenospora pallida, S. smilacina and $S$. kevorkianii occur on monocotyledonous hosts, namely Dioscorea, Smilax and on orchids, respectively. As a consequence of excluding $S$. xylopiae, Sphenospora is now restricted to species on monocotyledonous hosts (cf. Cummins and Hiratsuka 2003).

Sphenorchidium xylopiae and $S$. deightonii, which occur on the same host species, $X$. aethiopica, appeared as closely related but did not have identical sequences. Even the sample of $S$. deightonii from Gabon differed distinctly in its sequences of ITS, LSU as well as of SSU (Figs. 1, S1; Table S1) from $S$. xylopiae also collected in Gabon. Molecular data from the rDNA region indicate $S$. deightonii cannot be the aecial stage of $S$. xylopiae. There was no indication that $S$. deightonii was an endocyclic form based on morphological examination of herbarium material. The sequence differences found between the collections of $S$. deightonii from Guinea and Gabon (Figs. 1, S1; Table S1) were interpreted as intraspecific variability of a widely distributed species for the present because the aecia of them are morphologically indistinguishable and on the same host species. Maybe this interpretation will be revised when the corresponding telia will be detected and turned out to be different.

Endophylloides guineensis is an endocyclic form, which also occurs on $X$. aethiopica in West Africa, but it differs from $S$. deightonii in having spermogonia of group VI, type 5, and smooth teliospores adherent in columns and lacking peridia (Viennot-Bourgin 1959). A unique feature of this species is the strongly developed intercellular mycelium forming stroma-like layers below the upper leaf epidermis and around the telia (Viennot-Bourgin 1959). Without molecular data, the taxonomy of $E$. guineensis remains uncertain. The type species of Endophylloides, E. portoricensis Whetzel \& Olive [= Dietelia portoricensis (Whetzel \& Olive) Buriticá \& J.F. Hennen], appeared within the Puccinia clade in the molecular phylogenies (Fig. 1; Aime 2006), a group, which represents the Pucciniaceae s.str. that is characterized by spermogonia of group V, type 4 (Cummins and Hiratsuka 2003). Buriticá (1991) placed E. guineensis in the genus Ceratocoma. The only other species in Ceratocoma, the type species C. jacksoniae (Henn. ex McAlpine) Buriticá \& J.F. Hennen, has group V, type 4 spermogonia (Buriticá 1991). Thus, with type 5 spermogonia, E. guineensis belongs to neither Dietelia nor Ceratocoma, and the name E. guineensis is retained and should be used provisionally until further investigations clarify its systematic position.

Sphenorchidium xylopiae and S. deightonii were sister taxa to $P$. polyalthiae and $P$. popowiae in the molecular analyses but differ distinctly in their morphology. The wall ornamentation as well as the position and structure of germ-pores of the teliospores of $S$. xylopiae were conspicuously distinct from those of $P$. polyalthiae and $P$. popowiae. Telia of $P$. polyalthiae and $P$. popowiae were often associated with aecia, which are unknown for $S$. xylopiae. The aecia of $P$. polyalthiae and $P$. popowiae were characterized by relatively small aeciospores with thin walls, a fine-verruculose to verrucose ornamentation and refractive granules, and small broad ovoid peridial cells with verrucose ornamentation. Spermogonia were not found in either species. The aecia of $S$. deightonii are similar to those of $P$. polyalthiae and $P$. popowiae but in contrast are always associated with spermogonia. In the recovered phylogeny, the four species appeared together with the species of Dasyspora in a well-supported clade but differed very distinctly from them in teliospore ornamentation that has long branched projections at the poles and small lateral warts in Dasyspora. Sphenorchidium deightonii has spermogonia of group V, type 4 in contrast to Dasyspora, which has spermogonia of group VI, type 5 (Beenken et al. 2012).

However, the four species on Annonaceae fitted neither molecularly nor morphologically to any currently valid genera (cf. Cummins and Hiratsuka 2003). There were no previously proposed names that could be resurrected, such as Minnis et al. (2012) used for the recombination of Puccinia podophylli Schwein. to Allodus podophylli (Schwein.) Arthur. The morphological differences as well as the molecular data allowed the separation of $S$. xylopiae and $S$. deightonii from $P$. polyalthiae and $P$. popowiae.

It is interesting to note that the ecologically as well as economically important myrtle rust, $P$. psidii, which is invasive in many tropical countries on several genera of Myrtaceae (e.g., Simpson et al. 2006; Graça et al. 2013; Tan et al. 2014), also appeared in the well-supported clade of the new genera and Dasyspora but not in the Puccinia clades (Fig. 1). Thus, it also does not belong to the genus Puccinia and the Pucciniaceae s.str. (van der Merwe et al. 2008; Tan et al. 2014; Pegg et al. 2014). The taxonomy and nomenclature of $P$. psidii is quite complex. Hennen et al. (2005) listed 18 synonyms of $P$. psidii, Simpson et al. (2006) listed one further Puccinia species on Myrtaceae, P. cygnorum R. G. Shivas \& J. Walker, and Graça et al. (2013) assumed a "P. psidii complex" of several host associated bio-types. There exist a lot of older genus names, which are synonyms of Puccinia (e.g., www. speciesfungorum.org). Probably, one of them could be a candidate for the correct genus of $P$. psidii (cf. Minnis et al. 2012). That is why the erection of a new genus for it needs 
further, more extensive research which will form a separate publication.

Cummins and Hiratsuka (2003) placed the genera Diorchidium and Sphenospora in Raveneliaceae, but $D$. woodii, S. smilacina and S. kevorkianii appeared as members of the Pucciniaceae in the present phylogeny (cf. Aime 2006). The two new genera formed a monophyletic group with $P$. psidii and Dasyspora, but this group is morphologically quite heteromorphic. All species have pedicellate, twocelled teliospores with different orientations of septa. The ornamentation of teliospores are smooth in S. xylopiae and $P$. psidii, uniform spiny in $P$. polyalthiae and $P$. popowiae or with long projections and warts in Dasyspora. Spermogonia, an important character for definition of families (Cummins and Hiratsuka 2003), were only observed in S. deightonii and Dasyspora. Sphenorchidium deightonii has spermogonia of group V, type 4 in contrast to Dasyspora, which has spermogonia of group VI, type 5. Cummins and Hiratsuka (2003) placed Dasyspora in the Uropyxidaceae, a family that is polyphyletic (Aime 2006; Beenken et al. 2012); for example, the genera Macuropyxis, Porotenus, Prospodium and Tranzschelia assigned to Uropyxidaceae (Cummins and Hiratsuka 2003) appeared in several lineages of the Pucciniales (Fig. 1, arrowheads). The familial placement of the described genera is uncertain. Additionally, it is interesting that all species of this "Dasyspora-clade" come from the tropics of different continents: South America (Dasyspora, P. psidii), Africa (P. popowiae, S. xylopiae, S. deightonii) and Asia (P. polyalthiae).

In summary, two-celled pedicellate teliospores are widely distributed in the Pucciniales. Puccinioid teliospores were found in several distinct lineages of the presented phylogeny (Fig. 1). It must be concluded that this character is homoplasious and has convergently evolved in the Pucciniales.

Acknowledgments The author thanks the curators of B, BPI, K, M, NY, PREM, PC, PUR, S and Z+ZT for loan of specimens. The first author thanks the scientific and technical assistance of the Genetic Diversity Centre of ETH Zurich (GDC), where the molecular part of the study was done. R. Berndt (Zurich) kindly supported the present study funded by the Swiss National Fund (SNF) (project number 135624).

\section{References}

Aime MC (2006) Toward resolving family-level relationships in rust fungi (Uredinales). Mycoscience 47:112-122

Arthur JC (1926) Uredinales, additions and corrections. In: North American flora, vol 7, part 11:733-796

Beenken L (2014) Pucciniales on Annona (Annonaceae), with special focus on the genus Phakopsora. Mycol Prog 13:791-809. doi:10. 1007/s11557-014-0963-5

Beenken L, Berndt R (2010) Rust fungi on Annonaceae: the genus Sphaerophragmium. Mycologia 102(3):650-663
Beenken L, Zoller S, Berndt R (2012) Rust fungi on Annonaceae II: the genus Dasyspora Berk. \& M. A. Curtis. Mycologia 104:659-681

Berndt R (1996) Diorchidium taiwanensis sp. nov. (Uredinales) a new Diorchidium from Taiwan. Mycotaxon 59:253-257

Buriticá PC (1991) Familias del orden Uredinales con ciclo de vida completamente reducido. Revta Acad Colomb Cienc Exact Fís Nat 18(69):131-148

Castresana J (2000) Selection of conserved blocks from multiple alignments for their use in phylogenetic analysis. Mol Biol Evol 17:540 552

Cooke C (1882) Exotic fungi. Grevillea 10(56):121-130

Cummins GB (1971) The rust fungi of cereals, grasses and bamboo. Springer, Berlin

Cummins GB, Hiratsuka Y (1983) Illustrated genera of rust fungi, revised edn. APS, St. Paul

Cummins GB, Hiratsuka Y (2003) Illustrated genera of rust fungi, 3rd edn. APS, St. Paul

Doidge EM (1927) [1932] A preliminary study of the South African rust fungi. Bothalia 2:1-228

Edgar RC (2004) MUSCLE: multiple sequence alignment with high accuracy and high throughput. Nucleic Acids Res 32(5):1792-97

Gäumann E (1959) Die Rostpilze Mitteleuropas mit besonderer Berücksichtigung der Schweiz. Beitr. z. Kryptogamenflora d. Schweiz 12. Büchler, Bern

Graça RN, Ross-Davis AL, Klopfenstein NB, Kim M-S, Peever TL, Cannon PG, Aun CP, Mizubuti ESG, Alfenas AC (2013) Rust disease of eucalypts, caused by Puccinia psidii, did not originate via host jump from guava in Brazil. Mol Ecol 22(24):6033-6047

Hawksworth DL (2012) Integrating morphological and molecular data in fungal systematics. In: Misra JK, Tewari JP, Deshmukh SK (eds) Systematics and Evolution of fungi. CRC, Boca Raton, pp 1-14

Hennen JF, Sotão HMP, Winkler Hennen MM (1998) The genus Diorchidium in the Neotropics. Mycologia 90(6):1079-1086

Hennen JF, Figueiredo MB, de Carvalho AA, Hennen PG (2005) Catalogue of the species of plant rust fungi (Uredinales) of Brazil, Jardim Botânico do Rio de Janeiro, Rio de Janeiro: 1-490. http:/ www.jbrj.gov.br/publica/uredinales/Brazil Catalogue1drevisado. pdf

Huelsenbeck JP, Ronquist F (2001) MrBayes: Bayesian inference of phylogenetic trees. Bioinformatics 17:754-755

Huson DH, Richter DC, Rausch C, Dezulian T, Franz M, Rupp R (2007) Dendroscope - An interactive viewer for large phylogenetic trees. BMC Bioinf 8:460

Jackson HS (1926) The rusts of South America based on the Holway collections I. Mycologia 18(4):139-162, Plate 18

Kalchbrenner C, Cooke MC (1882) Fungi Macowaniani. Grevillea 11: $18-27$

Kropp BR, Hansen DR, Wolf PG, Flint KM, Thomson SV (1997) A study on the phylogeny of the dyer's woad rust fungus and other species of Puccinia from crucifers. Phytopathology 87:565-571

Lohsomboon P, Kakishima OY (1992) A monogroph of Hapalophragmium. Mycol Res 96(6):461-472

Maddison DR, Maddison WP (2003) MacClade 4.0. Sinauer Associates, Sunderland

Magnus P (1891) Beitrag zur Beleuchtung der Gattung Diorchidium. Ber Deutsch Bot Ges 9:187-193, plate 9

Maier W, Wingfield BD, Mennicken NON, Wingfield MJ (2007) Polyphyly and two emerging lineages in the rust genera Puccinia and Uromyces. Mycol Res 111:176-185

McNeill J, Barrie FR, Buck WR, Demoulin V, Greuter W, Hawksworth DL, Herendeen PS, Knapp S, Marhold K, Prado J, Prud'homme Van Reine WF, Smith GF, Wiersema JH, Turland NJ (2012) International Code of Nomenclature for algae, fungi and plants (Melbourne Code) adopted by the Eighteenth International Botanical Congress Melbourne, Australia, July 2011. Koeltz, Regnum Vegetabile 154: i-xxx, 1-208, http://www.iapt-taxon.org/nomen/main.php 
Minnis AM, McTaggart AR, Rossman AY, Aime MC (2012) Taxonomy of mayapple rust: the genus Allodus resurrected. Mycologia 104(4): 942-950

Pegg GS, Giblin FR, McTaggart AR, Guymer GP, Taylor H, Ireland KB, Shivas RG, Perry S (2014) Puccinia psidii in Queensland, Australia: disease symptoms, distribution and impact. Plant Pathol 63:1005-1021

Pfunder M, Schürch S, Roy BA (2001) Sequence variation and geographic distribution of pseudoflower-forming rust fungi (Uromyces pisi $\mathrm{s}$. lat.) on Euphorbia cyparissias. Mycol Res 105:57-66

Rambaut A, Suchard MA, Xie D, Drummond AJ (2014) Tracer v1.6. Available from http://beast.bio.ed.ac.uk/Tracer

Ritschel A, Berndt R, Oberwinkler F (2007) New observations of rust fungi (Uredinales) from northern Namibia. Mycol Prog 6:137-150

Ronquist F, Huelsenbeck JP (2005) MrBayes. Version 3.1.2. Bayesian analysis of phylogeny. GNU General Public License

Simpson JA, Thomas K, Grgurinovic CA (2006) Uredinales species pathogenic on species of Myrtaceae. Australas Plant Pathol 35:549-562

Stamatakis A (2006) RAxML-VI-HPC: maximum likelihood-based phylogenetic analyses with thousands of taxa and mixed models. Bioinformatics 22(21):2688-2690

Stamatakis A, Hoover P, Rougemont J (2008) A rapid bootstrap algorithm for the RAxML Web servers. Syst Biol 57(5):758-71

Sydow H (1925) Fungi in itinere costaricensis collecti. Ann Mycol 23: 308-429

Sydow H, Sydow P (1915) Novae fungorum species. XIII: Ann Mycol 13(1):35-43
Tan M-K, Collins D, Chen Z, Englezou A, Wilkins MR (2014) A brief overview of the size and composition of the myrtle rust genome and its taxonomic status. Mycology 5(2):52-63. doi:10.1080/21501203. 2014.919967

Thiers B (2011) [continuously updated]. Index Herbariorum: A global directory of public herbaria and associated staff. New York Botanical Garden's Virtual Herbarium. http://sweetgum.nybg.org/ $\mathrm{ih} /$

van der Merwe MM, Walker J, Ericson L, Burdon JJ (2008) Coevolution with higher taxonomic host groups within the Puccinia/Uromyces rust lineage obscured by host jumps. Mycol Res 112:1387-1408

Viennot-Bourgin G (1958) Trois Urédinales subtropicales nouvelles. Bull Soc Bot Fr 105:500-512

Viennot-Bourgin G (1959) Étude de micromycètes parasites récoltés en Guinée. Ann Inst Nat Agron, Paris 45:1-91

Vilgalys R, Hester M (1990) Rapid genetic identification and mapping of enzymatically amplified ribosomal DNA from several Cryptococcus species. J Bacteriol 172(8):4238-4246

White TJ, Bruns T, Lee S, Taylor J (1990) Amplification and direct sequencing of fungal ribosomal RNA genes for phylogenetics. In: Innis MA, Gelfand DH, Sninsky JJ, White TJ (eds) PCR protocols: a guide to methods and applications. Academic, San Diego, pp 315322

Yen J-M, Sulmont P (1970) [1969] Les Urédinées du Gabon. II. Un nouveau Sphenospora parasite du Xylopia: Spenospora xylopiae (nov. sp.). Bull Trimest Soc Mycol Fr 85 (3): 351-353 